\title{
ELAEOCARPUS (ELAEOCARPACEAE) ENDOCARPS FROM THE OLIGO-MIOCENE OF EASTERN AUSTRALIA
}

\author{
by Andrew C. Rozefelds and D.C. Christophel
}

(with two tables, two text-figures and three plares)

Rozefelds, A.C. \& Christophel, D.C., 1996 (30:vi): Elaeocarpus (Elaeocarpaceae) endocarps from the Oligo-Miocene of Eastern Australia. Pap. Proc. R. Soc. Tasm. 130(1): 41-48. https://doi.org/10.26749/rstpp.130.1.41

ISSN 0080-4703. Tasmanian Herbarium, GPO Box 252C Hobart, Tasmania, Australia 7001 (ACR); Botany

Department, University of Adelaide, PO Box 496, Adelaide, South Australia 5005 (DCC).

\begin{abstract}
Elaeocarpuspeterii sp nov. is described from the Oligo-Miocene Glencoe locality in central Queensland. This species has prominent stellate ridges and fine punctate ornamentation. These features support a close relationship to extant E. stellaris L.S. Smith from northeastern Queensland. Elaeocarpus clarkei (F. Muell.) Selling is redescribed. The punctate ornamentation and large oval endocarps of E. clarkei (F. Muell.) are closely comparable to extant E. bancroftii F. Muell. \& F.M. Bail. and E. linsmithii G.P. Guymer from north eastern Queensland. Elaeocarpus clarkei is a common element in many Oligo-Miocene deep leads in southeastern Australia. The age of some of the deep leads (buried placer deposits) in Victoria, e.g. Haddon and Foster, is discussed; the limited data available suggests a minimum mid-Miocene age for these localities.
\end{abstract}

Key Words: Elacocarpus, Elaeocarpaceae, endocarp, fruits, deep leads, Haddon, Foster, Glencoe, Tertiary, Miocene, Oligocene, Australia.

\section{INTRODUCTION}

Elaeocarpaceae is represented in the Tertiary fossil record in Australia by pollen, leaves and fruits. Fossil records of leaves or pollen have been referred to, or compared with the family generally, and not an extant genus (e.g. Christophel et al. 1987, Christophel \& Greenwood 1987, Hill \& Macphail 1983). In the Elaeocarpaceae, only Elacocarpus L. and Aceratium DC. have drupes. The endocarp in Aceratium is weakly lignified and has prominent and persistent mesocarp fibres. Elaeocarpus endocarps typically have woody and strongly ornamented endocarps and lack persistent mesocarp fibres. Elacocarpus has been recognised as a ubiquitous element of the Tertiary floras of Australia, because the woodyendocarps are robust and fossilise readily (Kirchheimer 1935, Selling 1950, Blackburn \& Sluiter 1994, Rozefelds 1990a, b, Rozefelds \& Christophel 1996).

The affinities of many of the fossil fruits that have been compared with, or referred to Elaeocarpus remain poorly studied. Penteune clarkei was described by Mueller in 1873 from deep leads (buried placer deposirs) in Victoria. Mueller referred this taxon to a new genus, the name alluding to the five valves of the endocarp. He was unsure of its generic and familial affinities but suggested it belonged "most probably to Sapindaceae, although the possibility of its having formed a genus of the Meliaceous order is not excluded" (Mueller 1874: 21). Selling (1950) recognised that $E$. clarkei F. Muell. was similar to extant E. bancroftii F. Muell. \& F.M. Bail. and referred it to Elacocarpus. A study of extant Elaecarpus species from New Zealand and Australia (Rozefelds 1990b, Rozefelds \& Christophel 1996 , Rozefelds \& Christophel, pers. obs.) shows that endocarp size and ornamentation is highly variable and groups of taxa within Elaeocarpus can be identified by endocarp morphology, particularly ornamentation type (Rozefelds \& Christophel 1996). The study of endocarp morphology in Elaeocarpus supported Selling's suggestion of a relationship between $E$. clarkei and E. bancroftii, but also identified similariries with orher taxa. In the present paper, endocarp morphology of these taxa is examined in detail. A new taxon, which also has punctate ornamentation, is described from the Glencoe locality, central Queensland. Similarities in endocarp morphology between the fossil taxa and extant Elaeocarpus taxa are recognised, and the biogeographical implications of these fossil taxa are discussed. A southern origin for the family is supported and two biogeographical hypotheses are proposed to explain the presence of the genus in the southeast Asian region.

\section{MATERIALS AND METHODS}

The early collections of fossil fruits are from deep leads that were mined for gold late last century in Victoria and New South Wales. These fruits were eirher donared to, or purchased for museum collections. Documentation of these early museum collections is often poor, with limiced strarigraphic information and collection details. The rype material of most of Mueller's taxa cannot be confidently idencified, because the published illustrations do not match the existing specimens, and the original specimens used in illustrations were nor identified. Some specimens have also partially disintegrated due to the oxidation of pyritic minerals in the fruits, and other material has decomposed completely. Material studied in this paper is from the Australian Museum (AMF), Museum of Victoria (NMVP), Geological Survey of New South Wales (MMF) and Queensland Museum (QMF).

The preservation of fossil material varies. The majority of E. clarkei material examined comes from deep leads in Victoria and New South Wales and the material is preserved as "charcoalified" fruits. Elaeocarpus clarkei from Elsmore is preserved as moulds with no internal structures preserved and no original rissue. The Glencoe specimen is silicified and some internal structures are present, although no organic rissue is preserved. Most of the comparative extant material of north Queensland Elneocarpus species was provided by CSIRO, Atherton (QRS). The material examined is listed in table 1. 
TABLE 1

List of extant Elaeocarpus spp. examined, including locality, collector and source of material

\begin{tabular}{|c|c|c|}
\hline Taxon & Locality & Collector \\
\hline \multirow{2}{*}{$\begin{array}{l}\text { Elaeocarpus } \\
\text { bancroftii } \\
\text { F. Muell. \& } \\
\text { F.M. Bail. }\end{array}$} & $\begin{array}{l}\text { SFR Little Pine L.A } \\
\text { eastern Queensland } \\
17^{\circ} 00^{\prime} \mathrm{S}, 145^{\circ} 50^{\prime} \mathrm{E}\end{array}$ & Gray 2328 (QRS) \\
\hline & $\begin{array}{l}\text { Noahs Creek and } \\
\text { Olivers Creek, Cape } \\
\text { Tribulation area, } \\
\text { NE Queensland, } \\
16^{\circ} 09^{\prime} S, 145^{\circ} 27^{\prime} \mathrm{E}\end{array}$ & ACR collection \\
\hline $\begin{array}{l}\text { E. linsmithii } \\
\text { Guymer }\end{array}$ & $\begin{array}{l}\text { Mt Bartle Frere, NE } \\
\text { Queensland, } 17^{\circ} 23^{\prime} \mathrm{S} \text {, } \\
145^{\circ} 48^{\prime} \mathrm{E}\end{array}$ & Hyland 13606 (QRS) \\
\hline \multirow[t]{2}{*}{$\begin{array}{l}\text { E. stellaris } \\
\text { L.S. Smith }\end{array}$} & $\begin{array}{l}\text { Barong L.A. State } \\
\text { Forest Reserve, NE } \\
\text { Queensland, } 17^{\circ} 30^{\prime} \mathrm{S} \text {, } \\
145^{\circ} 47^{\prime} \mathrm{E}\end{array}$ & Stocker 1774 (QRS) \\
\hline & $\begin{array}{l}\text { Coles Bay, } \mathrm{NE} \\
\text { Queensland, } 16^{\circ} 09^{\prime} \mathrm{S} \text {, } \\
145^{\circ} 27^{\prime} \mathrm{E}\end{array}$ & ACR collection \\
\hline
\end{tabular}

\section{LOCALITIES AND AGE}

Elaeocarpus clarkei has been collected from deep leads in Victoria (Haddon $37^{\circ} 36^{\prime} \mathrm{S}, 143^{\circ} 48^{\prime} \mathrm{E}$, Eldorado $36^{\circ} 18^{\prime} \mathrm{S}$, $146^{\circ} 32^{\prime} \mathrm{E}$, and Foster $38^{\circ} 39^{\prime} \mathrm{S}, 146^{\circ} 10^{\prime} \mathrm{E}$ ) and New South Wales (Bathurst $33^{\circ} 24^{\prime} \mathrm{S}, 149^{\circ} 35^{\prime} \mathrm{E}$ and Orange $33^{\circ} 17^{\prime} \mathrm{S}$, $149^{\circ} 05^{\prime} \mathrm{E}$ ). The Boola Boola [- $\left.38^{\circ} 04^{\prime} \mathrm{S}, 146^{\circ} 20^{\prime} \mathrm{E}\right]$ (Victoria) fruits are from bores (fig. 1). There have been numerous estimates of the ages of the Victorian and New South Wales deep leads ranging from Pliocene (Mueller 1874), Miocene (Walcott 1920), late Miocene (Macumber 1978) to Oligocene (Partridge \& Wilkinson 1982). Palynological evidence has provided information on the age of some leads, e.g. an Oligocene date for Loddon and Murray Basin leads (Martin 1977, Partridge \& Wilkinson 1982, Archer 1984).

While there is no a priori reason for assuming that the leads formed contemporaneously, the pulses of sedimentation required for their formation were probably related to periods of uplift, during the Tertiary, of the Eastern Highlands. King (1985), for example, considered that deep leads in the Haddon area were established during the early Tertiary, and initial deposition probably commenced during the Oligocene. There are no published palynological data or radiometric dates, known to the authors, to assist in dating the systematically diverse and historically important Haddon and Foster deep leads in Victoria, where most of the $E$. clarkei specimens recorded in this paper came from.

Elaeocarpus clarkei is recorded from the Orange locality in New South Wales. Radiometric dates of 10.9-12.7 Ma are recorded for basalts that overlie Tertiary sediments in the Orange area and indicate a minimum mid-Miocene age for this flora (Wellman \& McDougall 1974). While

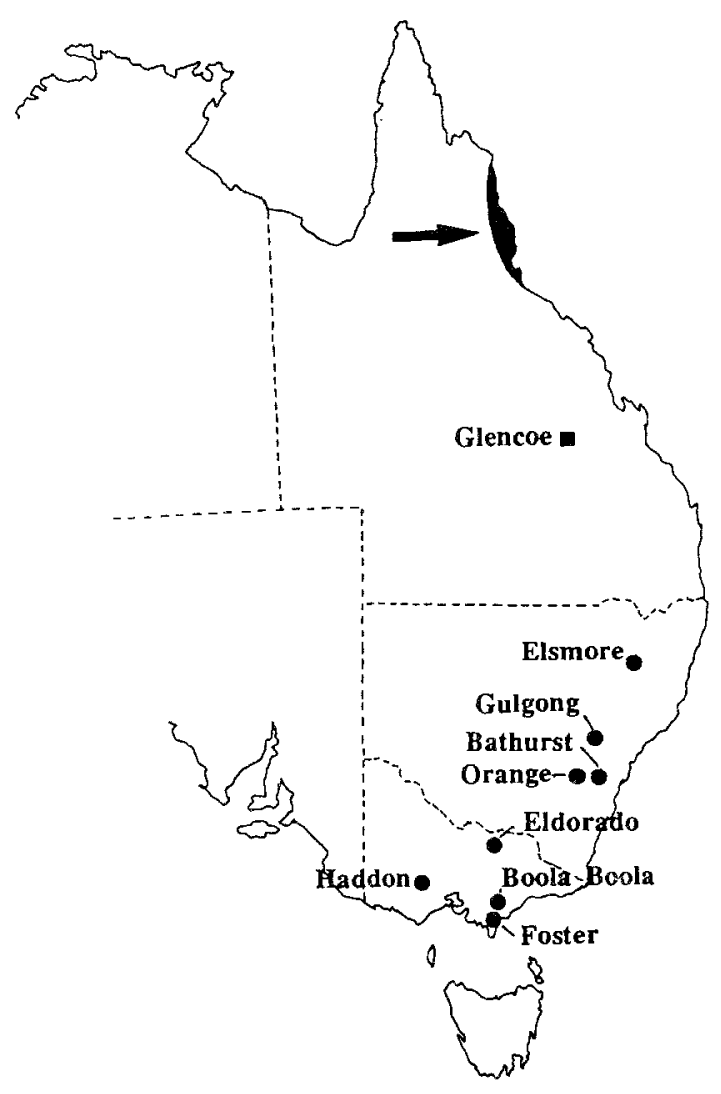

FIG. 1 - Localities mentioned in text and distribution of extant Elaeocarpus stellaris, E. bancroftii and E. linsmithii in northeastern Queensland arrowed. Localities for $\mathrm{E}$. clarkei are marked with a circle while the type locality for E. peterii sp. nov. is marked with a square.

the systematic and biostratigraphic relationships of the other fruits in these localities have not been critically reexamined, it is suggested, based upon the occurrence of Elaeocarpus mackayii (F. Muell.) Kirchheimer, Rhytidocaryon wilkinsonii F. Muell., Spondylostrobus smythii F. Muell. and Elaeocarpus clarkei at Haddon and Orange (Mueller 1874), that these localities are broadly contemporaneous. A minimum mid-Miocene age, possibly Early Miocene age is therefore suggested for the Haddon locality. The age of the other deep leads at Foster, Boola Boola and Eldorado, near Beechworth is unknown. The presence of E. clarkei in these localities similarly suggests that these floras are contemporaneous with those at Haddon.

The Elsmore locality $\left(29^{\circ} 47^{\prime} \mathrm{S}, 151^{\circ} 17^{\prime} \mathrm{E}\right)$ was referred to by Ettingshausen (1888). Fossil fruits are preserved as steinkerns (moulds). A recent survey of Ettingshausen's localities by Pickett et al. (1990) showed that two floras, in lithologically similar sediments (one Miocene in age and the other Oligocene), occur in the Elsmore area. The age of the original material collected is therefore uncertain, although a minimum Miocene age is indicated.

The data available for assessing the age and flora of the Glencoe locality has been discussed previously by Rozefelds (1990a). The silcretes with fossil plants overlie basalss, and a maximum age of $30 \mathrm{Ma}$ for this flora is suggested, based upon radiometric dates for nearby volcanics in this area 
(F.L. Sutherland, pers. comm., 1989). An Oligo/Miocene date for the flora is therefore likely.

\section{RESULTS}

One group of extant Elaeocarpus species, E. stellaris L.S. Smith, E. bancroftii F. Muell. \& F.M. Bail. and E. linsmithii Guymer are characterised by a relatively smooth endocarp with punctate ornamentation. The fossil taxa described in this paper also have this punctate ornamentation type. The three extant species also share prominent longitudinal pores in the endocarp wall. Elaeocarpus stellaris also has the unique feature of prominent stellate ridges on the endocarp, a feature shared with one of the fossil taxon being described here.

\section{SYSTEMATICS}

\section{Family ELAEOCARPACEAE Elacocarpus L.}

Type Species Elaeocarpus serratus L.

Elaeocarpus clarkei (F. Muell.) Selling, 1950: 558 Plate 1A-E, H-K,M.

Basionym: 1873 Penteune clarkei F. Muell., p. 1, pl. 7, figs 1-10 (plate 2 herein).

1874 Penteune clarkei F. Muell., pp. 20-21, pl. 7, figs 1-10 (republished the 1873 description and figures).

1925 Penteune clarkei F. Muell., in Deane (1925), p. 490, pl. 60, figs $1-3$.

Neotype (selected here)

AMF9281, Elsmore, New England District, New South Wales (pl. 1A-C).

A neotype is required because the type series figured by Mueller (1873) has not been located in museum collections in Victoria and New South Wales; it is presumed that it has been lost, has decomposed due to pyrites disease or cannot be positively identified from Mueller's original illustrations (pl. 2).

\section{Emended Diagnosis}

Elaeocarpus clarkei differs from other Elaeocarpus species in the following characters: large, thick, ligneous, usually five partite, rarely four partite endocarps with punctate ornamentation, the absence of persistent mesophyll fibres, and seedless locules compressed by growth of neighbouring seed.

\section{Description}

Ligneous endocarps, indehiscent, five partite, rarely four, ovoid to broadly ellipsoid, $25.4-40.5 \mathrm{~mm}$ long, 20.1-33.7 $\mathrm{mm}$ wide; variable in shape and size; apex rounded, surures recessed or confluent with endocarp surface; base rounded in outline, blunt or slightly pointed; Walls woody, up to 4.3-7.2 mm thick; surface irregular to moderately irregular, sometimes with a slight mid-sutural ridge down the middle of each section of endocarp; with irregular punctate ornamentation forming thin channels that extend into woody wall of endocarp. Seeds oval in lateral view and seedless locules compressed by development of neighbouring seed.

\section{Material examined}

Eldorado Gold Lead, Beechworth district, Victoria, NMVP53911-2, NMVP53917-9; Boola Boola district, Victoria, NMVP166541-3; Haddon district, Ballarat, Victoria, NMVP30586, NMVP53745, NMVP53805, NMVP53813, NMVP53907, NMVP53912, NMVP53915, NMVP53976, NMVP53978; Foster deep leads, Victoria, NMVP199904, NMVP1 99905; Victory Mine, Homebush Lead, Talbot, Victoria NMVP182177; Orange area, New South Wales, AMF8448; Bathurst, New South Wales, AMF51709; Forest Reefs, Orange, New South Wales, MMF10089-MMF10093, MMF10095.

\section{Remarks}

Selling (1950) referred Penteune clarkei to Elaeocarpus and, while noting the similarity with extant $E$. bancroftii, did not critically compare these two taxa. Elaeocarpus clarkei is similar to both extant $E$. bancroftii and $E$. linsmithii in the punctate ornamentation and relatively large, oval, thick, ligneous walled endocarps (pl.. 1). They differ in the number of parts in their fruits. A sample of over 1500 endocarps of Elaeocarpus bancroftii from a tree growing in the Cape Tribulation area in northeastern Queensland showed that $95.8 \%$ had four partite fruits, $2.6 \%$ had three partite fruits, and $1.6 \%$ had five partite fruits (Rozefelds, 1990b). Elaeocarpus clarkei differs from E. bancroftii in that the fruits are typically five partite, rarely four partite (pl..1). Elaeocarpus linsmithii is two partite, but as only one specimen of this species was available the infra specific variation is unknown. The base of the endocarp in E. linsmithii is acute in outline which differs from the rounded base of $E$. clarkei.

Mueller (1873) interpreted E. clarkei as having loculicidal dehiscence. Study of extant and fossil species in Elaeocarpus shows that the fruits are indehiscent, although they eventually split along sutures in the fruit. Elacocarpus clarkei also shows evidence of aborted ovules, and usually only one seed develops (pl.. 1M). The endocarps are typically divided by five sutures and are thus derived from a five locular ovary while in E. bancroftii the ovary is four-locular (Coode 1984).

Elaeocarpus clarkei is a relatively common taxon in southeastern Australia during the mid-Tertiary, as evidenced by the fossil record. Material figured is from Elsmore, New South Wales (pl.. 1A-C), Bathurst (pl.. 1D, E), Boola Boola, Victoria (pl.. 1H, I), Forest Reefs, Gulgong (pl.. 1], $\mathrm{K}$ ) and Haddon (pl.. 1M). The fruits figured from the different localities exhibit morphological variation in the number of depressions and endocarp size and shape (pl. 1; fig. 2). Material from Haddon is often partially degraded. One specimen from Boola Boola (pl.. 1H, I) has a weakly developed ridge (arrowed) down the middle of each part of the endocarp. The variation in size is considerably greater in E. clarke $i$ than that recorded for $E$. bancroftii (fig. 2). Additional eroded and partially disintegrated material is known from museum collections but is difficult to refer to this taxon because the surface ornamentation is not always preserved. Transverse sections of these endocarps, however, show the thin channels that perforate the endocarp wall. NMVP53811 is tentatively compared to E. clarkei but differs from most of the other material in that the apex is not rounded but obcordate in outline. Mueller (1873: 1) also notes that "an externally very similar fossil has been discovered in Tasmania by Morton Alport [sic], Esq., at Gerlston-Bay [sic, for Geilston] in Tertiary travertin". The whereabouts of this specimen remains unknown. 

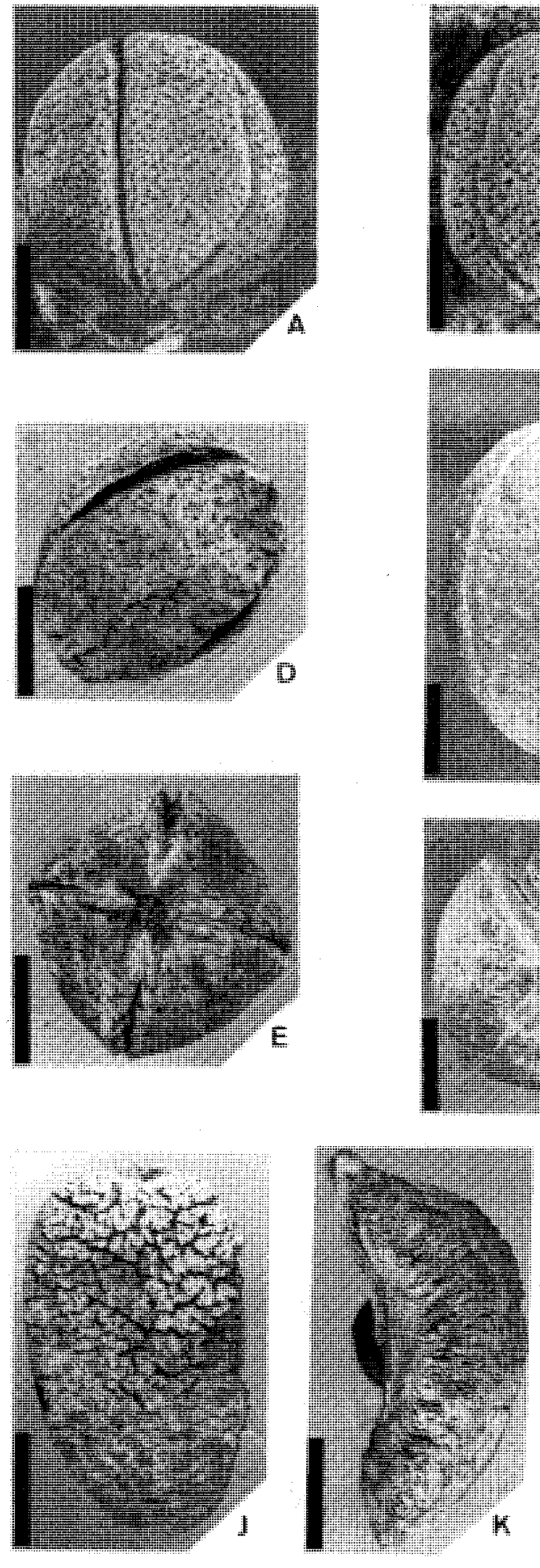
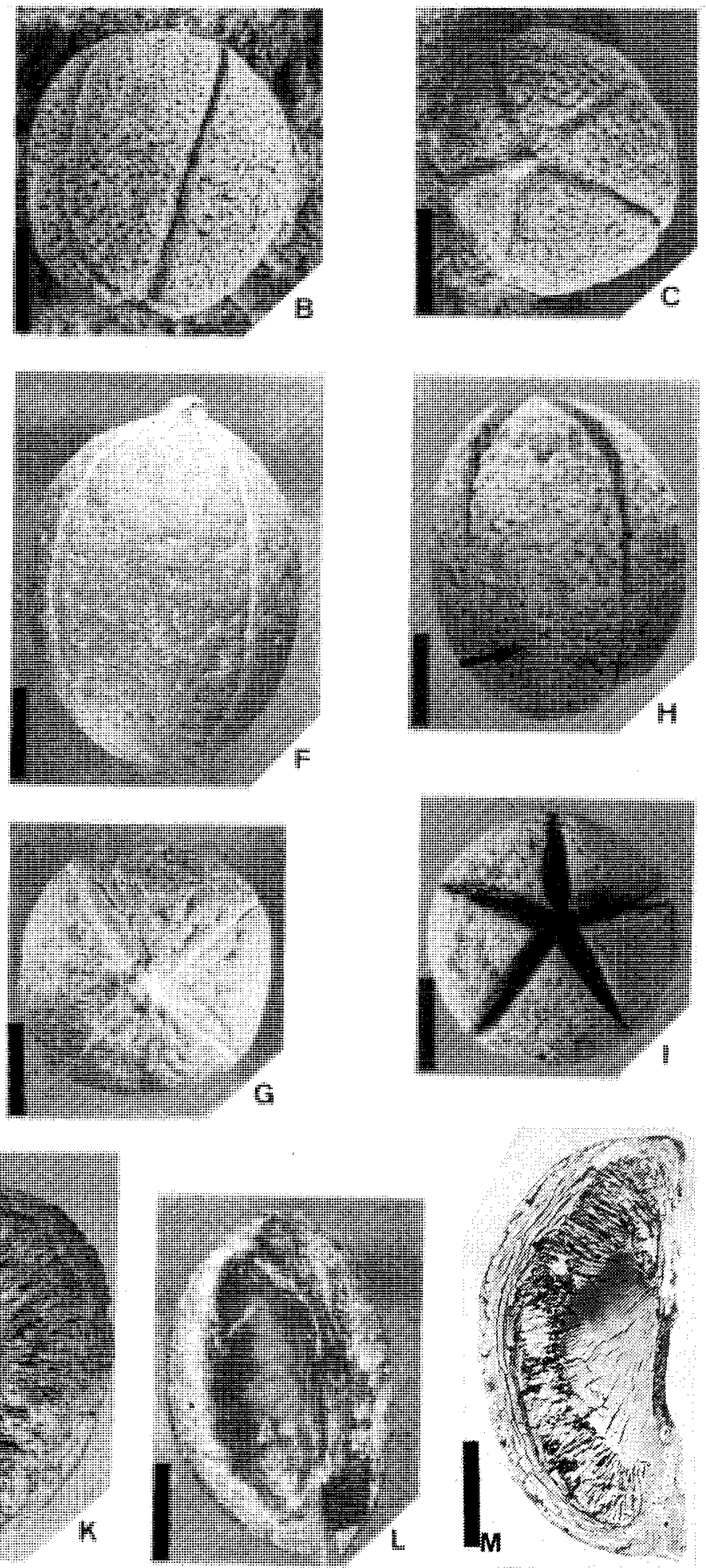

\section{PLATE I}

Fossil Elaeocarpus clarkei and extant E. bancroftii endocarps.

(A-C) Latex cast of E. clarkei mould from Elsmore, New South Wales (AMF9281). (A) showing apex; (B) Lateral view and (C) basal view. (D-E) E. clarkei, four partite fruit from Bathurst, New South Wales (AMF51709). (D) Lateral view and (E) apical view. (F-G) E. bancroftii: (F) lateral view; $(G)$ apical view (ex QRS, Gray, 2328). (H-I) E. clarkei from Boola Boola, Victoria (NMVP166542). (H) lateral view, arrow indicates weakly developed ridge; (I) apical view. (J-K) E. clarkei from Forest Reefs, Gulgong, New South Wales (MMF10089). (J) lateral view of a section of endocarp, showing fracturing in fruit wall, although the regular punctate depressions are still evident; $(K)$ internal view of endocarp wall. $(L)$ E. bancrofiii from Noahs Creek area, northeast Queensland. (M) E. clarkei from Smythes Creek, Haddon, Victoria; internal view of section of endocarp showing seed cavity. Scale bars $=10 \mathrm{~mm}$. 


\section{Elaeocarpus peterii Rozefelds \& Christophel sp. nov.}

Plate $3 A, C, E, G, I$.

\section{Holotype}

QMF18088.

Type Locality

Glencoe Station, Central Queensland, 23\% $6^{\prime} \mathrm{S}, 148^{\circ} 10^{\prime} \mathrm{E}$.

Etymology

Named after the collector, Peter Spackman from Glencoe Station, who kindly made the only known specimen available for study and sectioning. The family name, Spackman, is not used because a taxon E. spackmaniorum Rozefelds has been previously described from this locality.

\section{Diagnosis}

Elaeocarpus peterii differs from other species of Elaeocarpus by the combination of strongly woody endocarps, nonpersistent mesophyll fibres, fine punctate ornamentation of the endocarp and prominent lateral flanges that become less pronounced near the base.

\section{Description}

Endocarp, large, maximum diameter $27.5 \times 23.2 \mathrm{~mm}$ long, six partite, apex broadly rounded in outline with prominent circular stalk attachment scar, with base broadly acute. Prominent lateral flanges that extend down endocarp becoming less pronounced near base, flanges $6.7-8.1 \mathrm{~mm}$ wide and slightly variable in size, with sutures extending along their length, area berween flanges U-shaped, shallowing near base of endocarp. Surface generally smooth with small irregular ridges between the flanges at apex, and irregularly discributed fine depressions. Transverse section shows rare canals.

\section{Material}

Only the holotype is known from Glencoe Station, near Capella, central Queensland.

\section{Remarks}

The prominent flanged endocarp, sutures along flanges and generally smooth endocarp wall, with fine depressions, strongly suggest affinities with the extant northeastern Queensland species Elaeocarpus stellaris (pl. 3). The species differ, as E. stellaris has prominent flanges with distinct $U$ shaped depressions between flanges that extend the entire length of the endocarp (pl. 3B, D, F), whereas in E. peterii, the flanges raper towards the base (pl. 3A, C, E, G). Elaeocarpus stellaris typically has a five partite fruit (Coode 1984), although seven partite fruits also occur. The significance, if any, of a six partite fruit in $E$. peterii is difficult to assess. The central region of the endocarp in $E$. peterii is hollow, and replacement of internal endocarp structure has not occurred (pl. 3I). In E. stellaris, aborted locules occur, but the condition in $E$. peterii is unknown since the central region of the fruit is not preserved.

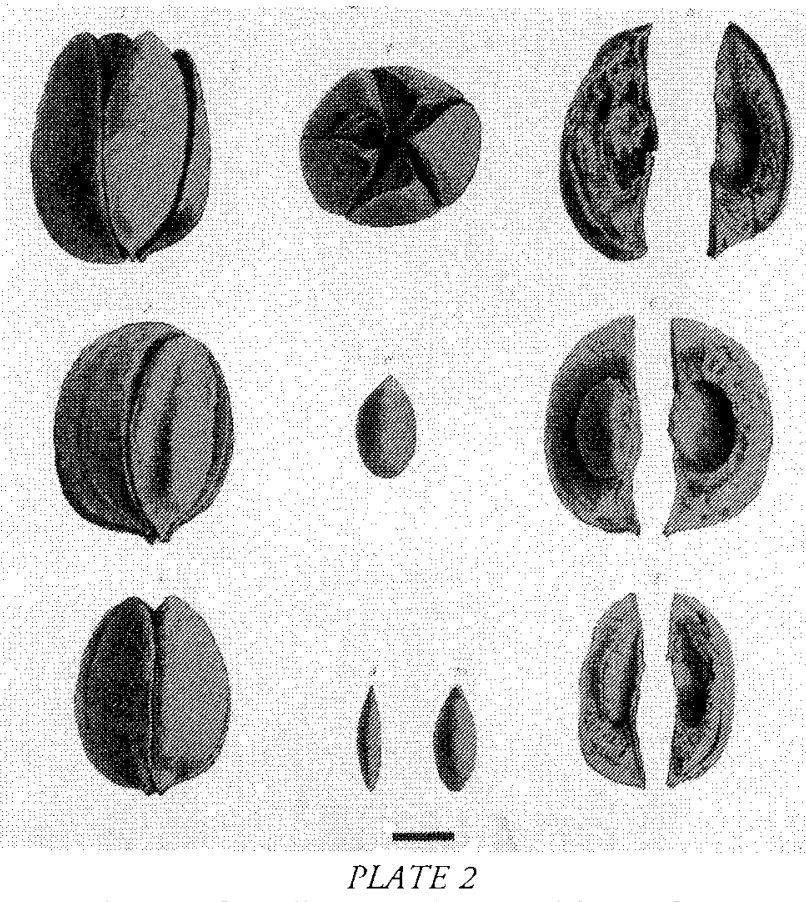

Reproduction of Mueller's (1874) original figure of Penteune clarkei. Scale bar $=10 \mathrm{~mm}$.

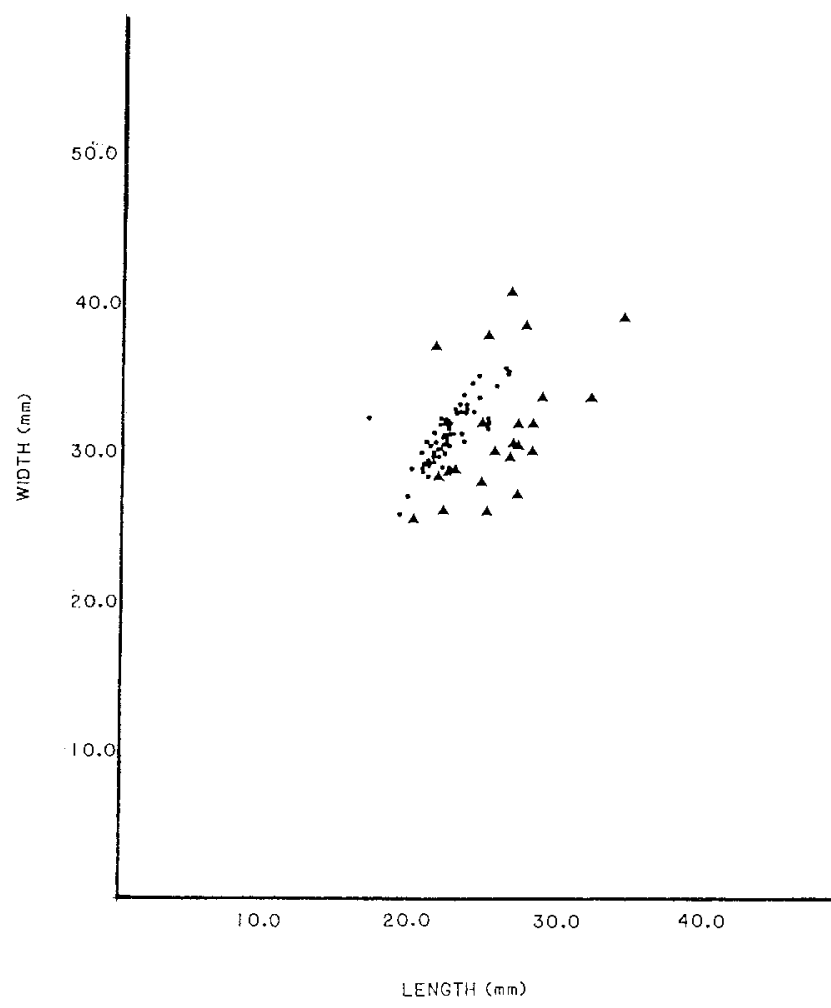

FIG. 2 -Variation in length and width of Elaeocarpus clarkei (triangles) and E. bancroftii (circles) endocarps. 

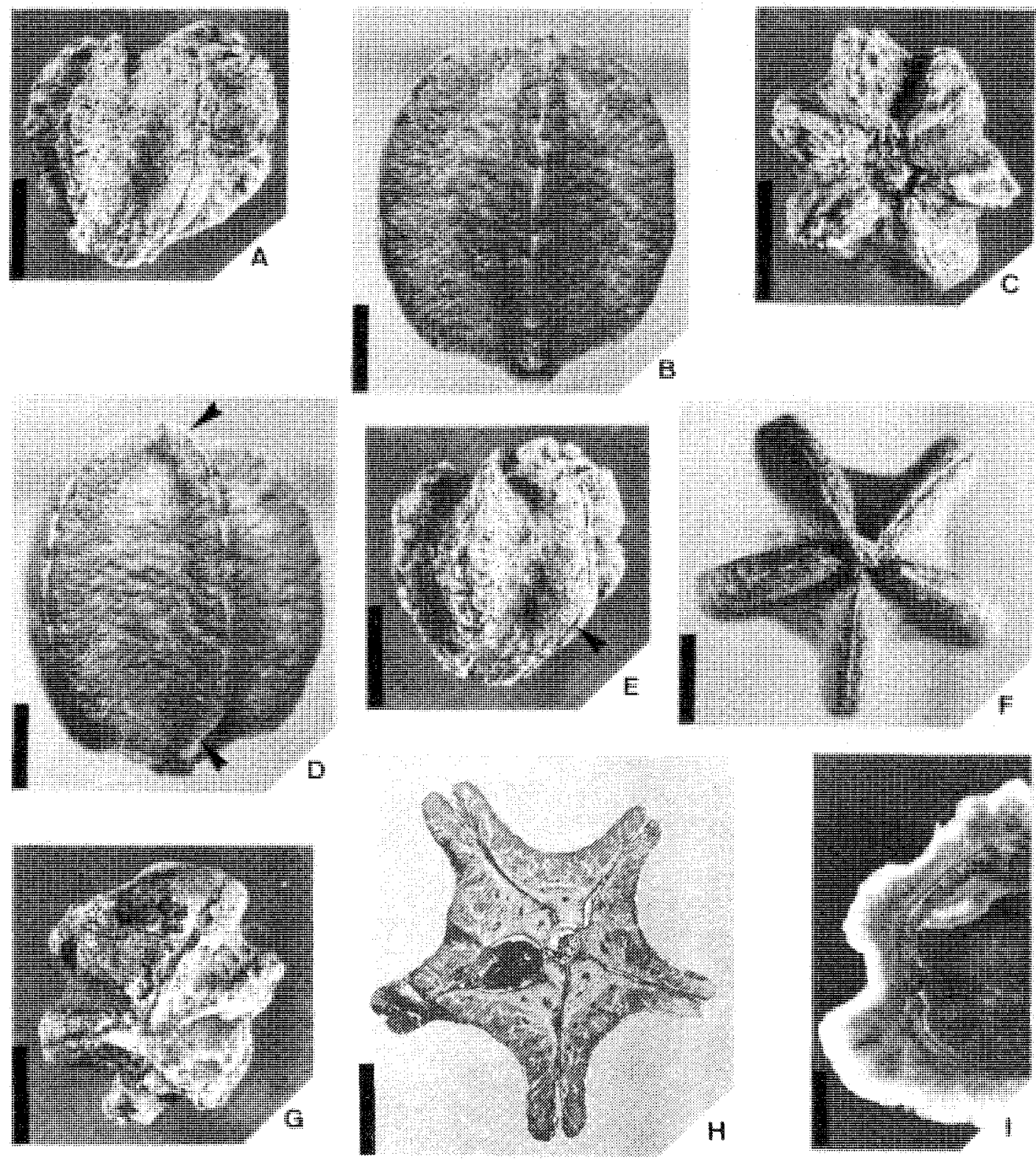

PLATE 3

Fossil Elaeocarpus peterii sp. nov. and extant E. stellaris endocarps.

$(A, C, E, G, I)$ Holotype of $\mathrm{E}$. peterii from the Glencoe locality, central Queensland (QMFI8088). (A, E) various lateral views, arrow indicates suture along flanges; $(C)$ apical view; $(G)$ basal view; (I) section through endocarp, shows a quartz-lined cavity and much of the inner portion of the endocarp is not preserved. $(B, D, F, H)$ Elacocarpus stellaris from Coles Bay area, northeastern Queensland (ex $Q R S$, Stocker 1774). (B, D) lateral views, arrows indicate sutures along flanges; $(F)$ apical view; E. stellaris, from author's (ACR) collection; (H) transverse section. Sale bars $=10 \mathrm{~mm}$.

\section{DISCUSSION}

Elacocarpaceae is generally considered to be Gondwanic in origin based upon the essencially southern distribution of many modern genera (Raven \& Axelrod 1972, 1974). The abundant Eocene leaf megafossil record (Tumbull 1986, Christophel \& Greenwood 1987, Christophel et al. 1987) in southern Australia indicates the family was widespread during the Early Terriary. Fossil wood referred to the Elacocarpaceac, from the Tertiary of India and the Paleocene of Patagonia, also atcests to a southern origin for this family (Prakash \& Daval 1964, Petriella 1972). Tertiary fruits from the London Clay Floras, England, have been referred to Sloanea (as Echinocarpus) but their placement within the genus has been questioned by Coode (1984).

The genus Elaeocarpus is widespread in the Indo-Pacific region from India, through Indo-China, Philippines, Indonesia to New Guinea and the Solomon Islands. It has disjunct outliers in Madagascar, New Caledonia, New Zealand and Hawaii (Raven \& Axelrod 1972, 1974, Tirel 1982). Within Australia, it is restricted to the eastern coast and parts of the Northern Territory. Elaeocarpus in Australia is essentially a rainforest genus restricted to mesic forest communities. Some of the extant Elacocarpus taxa in 
northeastern Queensland are considered closely related to rhese fossil taxa from southeastern Australia. This would suggest that the montane areas near Cairns and Mackay in north Queensland region are refugia for species with affinities to these fossil taxa. The tropical rainforest communities in North Queensland, with their edaphic and physiographic diversity, are the last refuges in Australia for some of these Tertiary groups. The reduction in range and/ or migration of taxa to refugial rainforest communities can be correlated with the increasing aridity of the climate from the Miocene onwards (Sluiter \& Kershaw 1982). This deterioration in climate is thought to be due to the initiation of the circum-Antarctic current following the final severing of contact between Australia and Antarctica (Kemp 1978, Truswell \& Harris 1982).

The fossil fruit record provides evidence that the genus was present on the Australian mainland prior to contact with the southeast Asian island arc. The fossil record of Elaeocarpus in Australia, as exemplified by the diversiry of fruir morphotypes in the mid-Tertiary in Australia, indicates that the genus was morphologically diverse at this time (Kirchheimer 1935, Selling 1950, Blackburn \& Sluiter, 1994, Rozefelds 1990a, b, Rozefelds \& Christophel, this paper, 1996). The fossil taxa E. clarkei and E. peterit, in parricular, have close affinities to modern species, e.g. E. bavcroftii and E. linsmithii, and E. stellaris respectively, that are restricted to rainforest areas in northeastern Queensland (fig. 2).

The mid-Tertiary fossil fruit record (Selling 1950, Rozefelds 1990a, b, Blackburn \& Sluiter 1994) from Australia suggests that the Australian plate could have been an important "corridor" for the evolution and radiation of parts of the genus into soucheast Asia. The fleshy fruits are eaten by birds, and bird-mediated dispersal into southcast Asia from Auscralia (Firth 1982) could have occurred towards the end of the Miocene, following contact with the Indo-Malaysian island arc (Johnson \& Briggs 1975).
Clearly bird-mediated dispersal is the explanation for the genus in Hawaii. Similarly, the presence of Elaeocarpus on the late Tertiary volcanic island arcs in the New Hebrides and Solomon Islands would again suggese dispersal of fruits by birds as the most likely mechanism. Fruit-eating pigeons, as one example, regularly utilise Elacocarpus fruits in their diet (table 2).

The alternative and probably ancillary explanation for the presence of Elaeocarpus in the southeast Asian region is rafting of micro-continental fragments from the northern rim of the Australian plate westwards. These fragments may have carried Gondwanic elements of the flora into the Indo-Malaysian region (Michaux 1991, Burrett et al. 1991), and parts of the Indonesian island arc are also likely to be Gondwanic in origin. A detailed phylogenetic analysis of taxa in the sourheastern Asian and Australian regions may help to elucidate which of these biogeographical scenarios is most likely.

\section{ACKNOWLEDGEMENTS}

We wish to thank the staff of the Australian Museum, Queensland Museum and Museum of Victoria and the Geological Survey of New South Wales for access to collections. The Museum of Victoria also provided funding for the visic of $A C R$, and staff kindly phocographed the original plates from Mueller's (1874) publication. Dr J. Douglas provided advice on the geology and access to unpublished literature on the deep leads of Victoria. Extant endocarp material used for comparative research was provided by the CSIRO Atherton (QRS). Thanks also to W. Longmore for advice on dispersal of fruits by pigeons. Our special thanks to the Spackman family, at Glencoe, for allowing ACR the opportunity to study the silicified fruit flora on their property. We thank Drs G. Kantvilas and G. Jordan and an anonymous reviewer for critical comments on the manuscript.

TABLE 2

Distribution and species of pigeons utilising Elaeocarpus fruits in their diet*

\begin{tabular}{|c|c|c|}
\hline Pigeon & Elaeocarpus species & Distribution of pigeon \\
\hline $\begin{array}{l}\text { Wompoo pigeon } \\
\text { Ptilinopus magnificus }\end{array}$ & $\begin{array}{l}\text { E. grandis, E. grahamii, } \\
\text { E. largiflorens }\end{array}$ & Northeastern Australia, New Guinea \\
\hline $\begin{array}{l}\text { Purple-crowned pigeon } \\
\text { Ptilinopus superbus }\end{array}$ & $\begin{array}{l}\text { E. grandis, E. largiflorens } \\
\text { E. arnhemicus, E. grahamii }\end{array}$ & $\begin{array}{l}\text { Northeastern Australia, New Guinea, } \\
\text { Moluccas, Sulawesi, Sulu Island, Aru Islands, } \\
\text { Bismarck Archipelago, Admiralty Islands, } \\
\text { Solomons }\end{array}$ \\
\hline $\begin{array}{l}\text { Torres Strait pigeon } \\
\text { Ducula spilorrhoa }\end{array}$ & E. grandis & $\begin{array}{l}\text { Northeastern Australia, Northern Territory, } \\
\text { New Guinea, Aru Islands, Bismarck } \\
\text { Archipelago, Admiralty lslands }\end{array}$ \\
\hline $\begin{array}{l}\text { Top knot pigeon } \\
\text { Lopholaimus antarcticus }\end{array}$ & E. kirtonii, E. grandis & Eastern Australia \\
\hline
\end{tabular}

* from Firth (1982) 


\section{REFERENCES}

ARCher, V., 1984: Palynological dating of samples from the Murray Basin deep leads, Victoria. Unpubl. Rep. Geol. Surv. Vict. 1983/107.

Blackburn, D.'T. \& Sluiter, I.R.K., 1994: The Oligo-Miocene coal floras of south eastern Australia. In Hill, R.S. (Ed.): HISTORY OF THE AUSTRALIAN VEGETATION: CRETACEOUS TO RECENT. Cambridge University Press, Cambridge: 328-367.

Burrett, C., Duhig, N., Berry, R. \& Varne, R., 1991: Asian and south western Pacific continental terranes derived from Gondwana, and their biogeographical significance. Aust. Syst. Bot. 4(1); 13-24.

Christophel, D.C. \& Greenwood, D.R., 1987: A megafossil flora from the Eocene of Golden Grove, South Australia. Trans. R. Soc. S. Aust. 111(3): 155-162.

Christophel, D.C., Harris, W.K. \& Syber, A.K., 1987: The Eocene flora of the Anglesea Locality, Victoria. Alcheringa 11: 303-323.

Coode, M.J.E., 1984: Elacocarpus in Australia and New Zealand. Kew Bull. 39(3): 509-586.

Deane, H., 1925: Tertiary fossil fruits from deep Lead, Foster, South Gippsland. Rec. Geol. Surv. Vict. 4(4): 489-492.

Ettingshausen, C. von, 1888: Contributions to the Terriary flora of Australia. Mem. Geol. Soc. NSW Palaeontol. 2.

FirTh, H.J., 1982: PIGEONS AND DOVES OF AUSTRALIA. Rigby, Sydney: $304 \mathrm{pp}$.

HILL, R.S. \& Macphall, M.K., 1983: Reconstruction of the Oligocene vegetation at Pioneer, northeast Tasmania. Alcheringa 7: 281-299.

Johnson, L.A.S. \& Briggs, B.G., 1975: On the Proteaceae The evolution and classification of a southern family. Bot. J. Linn. Soc. 70: 83-182.

Ke.mp, E.M., 1978: Tertiary climate evolution and vegetation history in the S. E. Indian Ocean Region. Palaeogeogr., Palaeoclimatol., Palaeoecol. 24: 169-208.

KinG, R.L., 1985: Explanatory Notes on the Ballarar 1:250 000 Geological Map. Geol. Surv. Vic. Rep. 75: 1-144.

KirChHeimer, F., 1935: Palaobotanische Mittcilungen 11. Das Vorkommen von Elacocarpus L. in den begrabenen goldseifen Australiens. Sonder Abdruck Zentralblatt f. min Abt. B. 5: 178-183.

Macumber, P.G., 1978: Evolution of the Murray River during the Tertiary period - evidence from northern Victoria. Proc. R. Soc. Vict. 90: 43-52.

MarTIN, H.A., 1977: The Tertiary stratigraphic palynology of the Murray Basin in New Sourh Wales 1. The HayBalranald-Wakool districts. Proc. R. Soc. NSW 110:4147.

Michaux, B., 1991: Distriburional patterns and tectonic development in Indonesia: Wallace reinterpreted. Aust. Syst. Bot. 4: 13-24.

MUeller, F. vON, 1873: New vegetable fossils of Victoria. Extracts from Reports of the Mining Surveyors and Registrars, Victoria: 2 pp.

MUeller, F. VoN, 1874: Observations on new vegetable fossils of the auriferous drifts. Dec. 1. Geological Survey of Victoria. John Ferres, Government Printer, Melbourne: $23 \mathrm{pp}$.
Partridcie, A.D. \& Wilkinson, H.E., 1982: Palynological examinations of samples from the Woodstock 10008 Bore, Loddon deep Lead. Unpubl. Rep. Geol. Surv. Vic. 1982/11.

PrTRletla, B., 1972: Estudio de maderas petrificadas det Terciaro Inferior del area central de Chubuc (Cerro Bororo). Revista Mus. La Plata H.s. 6: 159-254, pls 1-8.

Pickett, J.W., SmiTh, N., Bishop, P.M., Hill, R.S. Macphiall, M.K. \& Holmes, W.B.K., 1990: A stratigraphic evaluation of Ettingshausen's New England Tertiary plant localicies. Aust. J. Earth Sci. 37: 293-303.

PrAKASH, U. \& DAYAL, R., 1964: Fossil woods resembling Elaeocarpus and Ieea from the Deccan Intertrappean Beds of Mahurzaei near Nagpur. Palacobotanist 12(2): $121-127$.

Raven, P.H. \& Axelrod, D.I., 1972: Plate tectonics and Australasian paleobiogeography. Science N. Y. 176:13791386.

RAven, P.H. \& AXEIROD, D.I., 1974: Angiosperm biogeography and past continental movements. Ann. Mo. Bot. Gard. 61: $539-673$

RozefELDS, A.C., 1990a: A mid-Tertiary rainforest flora from Capella, central Queensland. In Douglas, J.G. \& Christophcl, D.C. (Eds): THIRD INTERNATIONAL ORGANIZATION OF PALAEOBOTANY SYMPOSIUM, 1988. A-Z Printers, Melbourne: 123-136.

Rozlfeldos, A.C., 1990b: A taxonomic study of extant and fossil fruits of the genus Elacocarpus (Elacocarpactae) in Australia and New Zealand. Unpubl. Hons thesis, Bot. Dep., Univ. Adelaide.

Rozbrelos, A.C. \& Christophel., D.C., 1996: Elacocarpus (Elaeocarpaceae) endocarps from the Early to Middle Miocene Yallourn Formation of eastern Australia. Muelleria (in press).

Selling, O.H. 1950: Some Tertiary plants from Australia. Svensk Bot. Tidskrift 44 (4): 551-561.

StuItER, I.R. \& KERSHAW, A.P., 1982: The nature of late Tertiary vegetation in Australia. Alcheringa 6: 211-222.

Tirel, C., 1982: Éléocarpacées. In Aubréville, A. \& Lefroy, J.-F. (Eds): FLORE DE LA NOUVELLE CALEDONIE E1 DÉPENDANCES. Vol. II. Musétum National D'Histotre Naturelle: $3-124$

Trusiwell, E.M. \& Harris, W.K., 1982: The Cainozoic palaeobotanical record in arid Australia: fossil evidence for an arid adapted flora. In Barker, W.R. \& Greenslade, PJ.M. (Eds): EVOIUTION OF THE FLORA AND FAUNA OF ARID AUSTRALIA. l'eacock Publ., South Australia: 67-76.

Turnbuli. M., 1986: A numerical taxonomic study of the leaf archirecture of the southern, tropical-temperate rainforest family Elacocarpaceae. Unpubl. Hons thesis, Bor. Dep., Univ. Adelaide

WALCOTT, R.H., 1920: Evidence of the age of some Australian gold drifts, with special reference to those containing mammalian remains. Rec. Geol. Surv. NSW 9(2): 66-97.

Wellman, P. \& McDougiall, I., 1974: Potassium-argon ages on Cainozoic volcanic rocks of New South Wales. I. Geol Soc. Atst. 21: 247-272.

(accepted 15 August 1995) 